\title{
ANTOLOGIA DA ACADEMIA MARANHENSE DE LETRAS: 1908*1958.
}

São Luís: Academia Maranhense de Letras/ CEUMA Universidade, 2007, 263p.

A Academia Maranhense de Letras, fundada em 1908, completou, em 1958, seus 50 anos. Em 2007, seu então presidente, Joaquim Itapary e um grupo do sodalício desejaram publicar, em técnica fac-similar, a edição lavrada em 1958.

O propósito residiu em que, como diz o seu presidente: "Esta é uma obra rara, de edição esgotada. É, para a academia, um documento de alto valor relativo à sua história. Em razão dessa inegável significação histórica, a Comissão Editorial decidiu republicá-la, preservando, assim, a integridade do texto original."

Solicitada a participação da Universidade CEUMA, esta fez editar trezentos exemplares a título de colaboração.

O livro contém cento e quatro autores, prosadores e poetas, professores, advogados etc., com suas respectivas bibliografias.

Como se observa, houve uma ideia feliz dos organizadores em casar as biografias com um texto de um dos trabalhos produzidos, de maneira que o leitor se informa sobre os lances vivenciais dos escritores e suas obras.

Assim sendo, somos sabedores de mil e uma peripécias a respeito da vida dos acadêmicos, por exemplo: sobre Gonçalves Dias, fica-se sabendo que foi filho "de um reinol transmontano, comerciante de profissão, e de uma mestiça”; de Raimundo Teixeira Mendes, o leitor fica a par de que "estudou primeiramente num colégio jesuíta do Rio e, em seguida, no Pedro II, demonstrando sempre inteligência viva e aplicação incomum". Como se observa, uma galeria de fatos e fenômenos humanos interessantíssimos.

À página 257, o ex-presidente da República, José Sarney Costa, é analisado em um poema singular, lavrado para sua filha Roseana. Assim, sabemos que ela era e é “anjo e pássaro agora sou/o teu sorriso me prolonga/além do dia, além da noite”.

Portanto, a Antologia da Academia Maranhense de Letras, em sua edição cinquentenária, mais do que um documento cultural, é uma amostra irretorquível de carinho pelos nossos escritores, de cuidado pela nossa cultura e de acendrado civismo e amor eterno pelo Maranhão. 